\title{
INTEGRATING FINANCIAL ANALYSIS INTO PRESENTATIONS
}

Elizabeth Saatci

Bilkent University

ASSIGNMENTS THAT COMBINE case studies with applied research can work for presentations as well as for written reports. As Morton (2000) points out, combining case studies with original research

allows students to benefit from the challenges in each approach-the sharp focus and constraints found in case studies as well as the challenge of conducting original research and showing its correlation to specific situations-thereby alleviating student frustrations that something is missing. (p. 83)

One such assignment that has proven to be successful both in my classes and later in the students' professional lives is based on

- incorporating banking concepts and encouraging their use in presentations

- collecting financial data, analyzing it, and presenting it visually

- boosting students' confidence and fluency when presenting to a specific audience

This case/research fusion leads to a 10-minute oral presentation given by every student. It also involves teamwork because it includes a problem-solving element (see Appendix A). This article briefly profiles the students for whom the assignment was created, describes the assignment, and evaluates the outcome of this assignment.

Business Communication Quarterly, Volume 67, Number 3, September 2004 316-326 DOI: $10.1177 / 1080569904268105$

() 2004 by the Association for Business Communication

316 


\section{STUDENT PROFILE}

The business communication course is given to 3rd-year banking and finance/accounting undergraduate students at Bilkent University, Ankara, Turkey. The students follow a unique program popular in European universities where foreign languages are combined with a particular specialization. At Bilkent University, banking and finance studies are combined with English, French, and Turkish. The banking and finance component of the curriculum is professionally oriented, and the business communication courses in English and French play an important role in integrating banking, finance, and accounting concepts into meaningful case studies that culminate in oral presentations, business report writing, and negotiations. All students are Turkish, and their level of language competence ranges from upper intermediate to advanced for both English and French. Thus in speeches and presentations, language input, such as appropriate signpost words, phrases, and practice in stress and intonation, is necessary at every stage of the presentation (effective openings, introduction, purpose, body, conclusion, and question and answer) for fluency to be attained.

\section{THE ASSIGNMENT}

The oral presentation assignment is designed for 3rd-year undergraduate students in banking and finance/accounting. Before engaging in this assignment, students have taken both accounting and business communication courses and thus have a basic knowledge of accounting as well as an ability to write short reports and conduct meetings.

For this assignment, students are asked to select a company listed on the Turkish stock exchange. Having selected the company, they conduct some preliminary research to discover its long-term strategic plans (as defined in the corporate strategy) and the objectives for funding. Then in the role of the company's chief financial officer (CFO), students have to prepare a 10-minute presentation to give to a team of bank executives to request funding for their fixed assets/working capital requirements to attain the long-term strategies. The bank executives' team consists of at least six members (rotating teams), and their main concern is to assess the risk involved in providing the funds. To do that effectively, they need information about safety, profitability, and liquidity; forecasts of sales revenues and cash flow; and information about the type of business and industry the company is in. In a 10-minute presentation, the CFO needs to persuade the bank executives to provide the 
requested funds (the amount is to be determined by the student based on information collected) to the company. Limited by the time allocated to the presentation, the student must select only the information that the audience needs to make a positive decision.

\section{Selecting Information}

In this assignment, teachers of business communication can guide students in selecting the information needed to assess the key criteria of safety (the excess of assets over liabilities and ability of the firm to meet the principal and interest payments on the debt), profitability (the ability of the company to earn profit over a period of time), and liquidity (the ability of the company to pay its debts as they fall due), thus addressing the bank executives' needs. In sifting information, students should pay close attention to the company's financial statements for the past 3 years. From the income statement, they examine sales, gross income, net income, and interest expenses. From the balance sheet, they find current assets, current liabilities, inventories, long-term liabilities, and shareholders' equity.

After selecting the relevant items from these documents, students use ratio analysis and interpret the results to identify a trend (see Appendix B). In doing so, they need to determine the reasons for that trend and compare their company's performance with those of similar businesses within the sector to get a better picture. Although this picture of past company activity can help predict future performance and thus risk, in practice, students need a more detailed view. Sales forecasts obtained from primary data can help them predict future sales revenues and costs (taking inflation into account), and a forecasted cash flow can be constructed. This will show the expected flows of cash into and out of the business in the immediate future (for example, 6 months).

\section{Preparing and Delivering the Presentation}

Having obtained and analyzed the necessary information, students next need to structure the presentation, elaborate it with visuals where necessary, and practice the language to be used to make it a successful presentation.

The presentation is then delivered to the team of bank executives, which, in turn, asks questions to clarify points that will help in making a decision. Equipped with their notes, the executives convene a meeting to decide which company should obtain the loan. The final decision is 
then communicated to the CEO of the bank in a short report written by the team.

The time needed to complete the assignment ranges from 4 to 6 weeks depending on the number of students (large classes would require more time for the presentations). I need approximately 4 weeks for the presentations for an average class size of 45. Research for relevant information can be found in the selected company's latest annual report, which provides the past 3 years' figures. Primary research is essential for expected sales figures. Other sources include annual studies by industry published by reputable banks, the press, and the sponsors of various financial Web sites.

\section{THE CFO'S ROLE}

To help the student-CFO persuade the executives, we spend time in class analyzing the bank executives' concerns (in this case, the risk involved and concerns about profitability, liquidity, and security). Having developed the key ratios, the student has a better understanding of the situation his company is in, how strong or weak the company's performance is in comparison to similar firms in the same sector, and the possible impact these figures could have on the bank's business. Favorable figures and positive trends are what students are hoping to find and present to achieve the objective of satisfying the bank's concerns and obtaining the loan. If the opposite occurs, then they need to continue their research to find other equally convincing strong points, such as cost-reduction measures and expected income, increasing market share, new product to be launched, and the positive impact these would have on profitability. As Oakes (2001) said, the presenter should be fully aware that "the solution presented should be able to meet the customer's needs while being mindful of the customer's worries about potential risks, costs, and implementation problems" (p. 12).

\section{Visuals}

Armed with this information, the student can then reflect on the structure of the presentation and the incorporation of visuals. The problem faced here is that many students rely on using as many visuals as possible (for example, eight visuals for a 10-minute presentation); in class, we limit them to two or three. In selecting the visuals, students must ensure that they actually contribute to the points they wish to draw attention to and should avoid, as Teun De Rycker (2001) pointed out, 
"cherry-picking their way through the data in search of whatever may support a claim, justify a decision, or illustrate a fact" (p. 73). Consequently, De Rycker's data analysis worksheet becomes a useful tool in helping students decide which visuals to include and subsequently how to generalize and explain the visual. According to De Rycker, "They should be able to spot patterns, identify trends, and discover similarities and differences. In addition, students should be able to report their interpretations in an informative way, using an appropriate range of linguistic choices and combinations" (p. 74).

\section{Language Input}

While students are preparing for the delivery of the presentation, attention is drawn to varying the presentation style and content with voice modulation, pauses, and nonverbal communication. Because this is supposed to be a persuasive presentation given by students for whom English is a foreign language, this stage of the presentation is crucial for the overall success of the whole presentation and for building student confidence and fluency. Here a great deal of effort is put into practicing stress and intonation. Extracts of speeches are given without any punctuation and in uppercase letters, on which students have to mark the breath pauses and underline the stressed words throughout. Following this, they listen to the oral version of the extract given by a native speaker and try to imitate it. Pauses and repetitions are also elicited, with the instructor making sure the students understand that these are important aspects in this type of presentation. Equally important is providing language input (signpost words, tags, and intensifiers) and ready-made sentences (see Appendix C), in particular for students with high communication apprehension. Learning these phrases and sentences contributes a lot to boosting their confidence, especially in the first minutes of the presentation.

\section{THE BANK EXECUTIVES' ROLE}

All students play the role of bank executive on rotating teams of six members each. The advantage is that they now become the audience and are more alert to the specific items that need to be answered. Assuming responsibility for asking pertinent questions and deciding who will get the loan are two factors that render this activity exciting. Questions range from the very specialized, usually asked by students who are number-minded and finance-oriented, to more general 
questions asked mostly by linguistic-oriented students, who are often wary of financial explanations. Peer interaction is thus achieved in an atmosphere that is not very different from the one encountered in a real-life situation.

\section{The Meeting}

To decide who the beneficiary of the loan will be, the students forming the bank executives' team convene a meeting. For the meeting, a chairman is appointed and required documentation is prepared (notice, agenda, minutes). Once a decision is reached, the team writes a short memo report to the CEO, informing him or her of the decision and providing an explanation. The meeting documents and short report are then submitted for grading.

\section{EVALUATING THE ASSIGNMENT}

Despite the fact that the first reaction to this assignment is one of apprehension, the feedback in course evaluations and discussions with graduates indicates that they appreciate this particular assignment because the skills learned can be implemented in the workplace and, more important, because they feel that thanks to these particular skills, they are preferred to other candidates during interviews. What, as a result of this assignment, makes the students feel more confident? Here are excerpts from student comments:

- A better grasp of some basic concepts in finance and a realistic application of ratio analysis. (Students working in banks e-mail comments to me about how they outshine their colleagues at work with their practical knowledge!)

- The ability to communicate orally in a clear and organized manner, keeping the audience in mind. (Feedback from discussions indicates that students tend to impress others with the facility and fluency that they exhibit, especially during interviews where they are asked to give short presentations. This is because audience-oriented presentations are not the norm in Turkey, and the preferred delivery method is by reading.)

- The opportunity to deal with a case that involves a number of communication skills: presentations, meetings, and short written reports.

- The opportunity to conduct both primary and secondary research for data collection and to perform numerical calculations with the data obtained to derive a logical conclusion.

- A greater awareness of the use of language and its importance in presentations. 
Equally important, this assignment can be adapted by instructors who wish to combine concepts from a particular discipline to achieve a realistic outcome, such as a request for funding. This motivates students, who become personally involved as they are challenged twice in an atmosphere of competition and cooperation: competing with others to obtain a loan and cooperating with other team members to select the company with the lowest risk to which a loan will be granted. Apprehension felt for the presentation quickly disappears for most students as they get involved in the case, and once it is over, they are amazed at what they have achieved.

\section{APPENDIX A PART A: ORAL PRESENTATION}

Assume the role of the CFO of company XYZ, listed on the Turkish stock exchange. Your company aims to continue implementing its strategic plans, despite the economic crisis in Turkey. (Find out which one corresponds to your company, e.g., market penetration, market development, product development, diversification, restructuring, merger or acquisition, etc.) As the CFO of the company, you need to secure financing to cover the costs of the projects undertaken. At a recent meeting, your colleagues and you discussed the issue and considered all possible options of raising capital. It was decided that the best option was to get a bank loan. Unfortunately, because of sweeping bank reforms in Turkey, all Turkish banks are unwilling to provide any loans. You are aware, however, that foreign banks sometimes provide capital to companies if they are interested in what they hear. You have already contacted some of them, and today you have been informed that Bank ABC is interested in your case and has invited you to give a presentation to the bank executives' team.

While preparing for your presentation, keep in mind that most bankers are concerned with safety, liquidity, and profitability when they give loans to companies. So try to convince the Bank ABC executives to lend you the money you need!

\section{Tasks}

- Collect information from libraries, company annual reports, interviews, newspapers, magazines, and the Internet.

- Review the company's financial statements, for example, income and expenditure account, and balance sheet for the past 3 years. Calculate financial ratios that measure the current financial performance (safety, liquidity, profitability). 
- Assess the future financial performance by providing sales and cash flow forecasts.

- Prepare an outline.

- Prepare visual aids to be incorporated into your presentation. These will be displayed using PowerPoint.

- Give the presentation. Sessions will commence on the ...

\section{Assessment}

Four aspects of oral presentation will be assessed:

- Design of presentation: Adequately introduced and concluded, clearly arranged, and focused on main points?

- Visual aids: Well designed, appropriate to purpose, effectively used?

- Presentation: No or few notes, points clearly stated and connected, fluent, good contact with audience?

- Content: Plausible claims, good explanations or arguments, good supporting evidence? Credible answers to questions from audience?

\section{PART B: MEETING AND SHORT REPORT}

Assume the role of a bank executive. Forming a team of bank executives from Bank ABC, you will meet each of the companies and listen to their presentations. Using the question and answer session of the presentation, you will use this time (about 3 minutes) to ask relevant questions that will further enable you to assess the risk in providing funds (Cotton, 1988).

\section{Tasks}

- Meet with members of the group and plan the questions to be asked.

- Every member should ask a question during the question-answer session of the presentation.

- After the presentation, convene a meeting to decide which company deserves to get the loan.

- For the meeting, prepare a notice and an agenda and write a minute report of the discussion/decisions made.

- Write a memo report to the $\mathrm{CEO}$ of $\mathrm{ABC}$, giving the reasons that led you to the decision that you have made.

\section{Assessment}

- Submit a narrative minute report of the meeting.

- Submit a memo report, giving reasons for the decision reached by the team. 


\section{APPENDIX B}

\section{Common Ratios}

\section{LIQUIDITY}

Measures the firm's ability to pay its bills when they come due.

\section{Current Ratio}

The current ratio is the most commonly used measure of the liquidity of a company. It is simply a commonsense measure. The numerator is the value of assets that should be converted into cash within the next year. The denominator is the amount of bills coming due within the next year. The average for all manufacturing companies is roughly two (2.0). However, the industry average varies greatly from industry to industry.

$$
\text { Current Ratio }=\frac{\text { Current Assets }}{\text { Current Liabilities }} .
$$

\section{Quick Ratio}

The quick ratio (or acid test ratio) is a more restrictive measure than the current ratio. The numerator consists of the most liquid current assets. The average for all manufacturing companies is about one (1.0). This average also varies a great deal from one industry to another.

$$
\text { Quick Ratio }=\frac{\text { Current Assets }- \text { Inventory }}{\text { Current Liabilities }} \text {. }
$$

\section{SAFETY}

Measures the ability of the firm to meet its principal and interest payments on the debt.

\section{Debt Ratio}

Indicates the percentage of the total assets that have been financed by debt.

$$
\text { Debt Ratio }=\frac{\text { Total Debt (or Liabilities) }}{\text { Total Assets }} .
$$

\section{Debt-to-Equity}

A variation of the debt ratio. Measures the money invested by creditors relative to the money invested by the owners.

$$
\text { Debt-to-Equity Ratio }=\frac{\text { Total Debt }(\text { or Liabilities })}{\text { Total Equity }} \text {. }
$$




\section{Times Interest Earned}

A key measure of the firm's ability to meet its interest payments. The numerator is the amount of earnings available to meet interest payments. The denominator shows the amount of those interest payments.

$$
\text { Times Interest Earned }=\frac{\text { Net Operating Income (or E.B.I.T.) }}{\text { Interest Expense }} \text {. }
$$

\section{PROFITABILITY}

\section{Return on Investment}

Measures the profitability per dollar investment in the firm.

$$
\text { Return on Investment }=\frac{\text { Earnings After Taxes }}{\text { Total Assets }} .
$$

\section{Return on Equity}

Measures the profitability per dollar of investment in the firm by the owners.

$$
\text { Return on Equity }=\frac{\text { Earnings After Taxes }}{\text { Total Equity }} \text {. }
$$

\section{Gross and Net Profits}

Measures the contribution to gross and net income that each sales dollar generates.

Gross profit margin $=\frac{\text { Gross Income }}{\text { Sales }}$.

$$
\text { Net profit margin }=\frac{\text { Net Income }}{\text { Sales }} .
$$

\section{APPENDIX C}

Useful Phrases to Help Structure a Presentation

\section{PREPARING THE AUDIENCE}

I'm going to be talking about . . .

I'll start with . . . and then move on to . . Finally, I'm going to . . .

Let me start by . . . First of all, I'll . . .

Starting with ... 
I'd like to begin by . . .

The purpose of my presentation is ...

So, in my presentation today I'm going to explain ... and outline the ...

\section{DELIVERING THE MESSAGE}

Firstly, ... Secondly, ...

First I'll give you ...

Then, I'll go onto examine ...

Lastly, I'll explain ...

This brings me to my first point ...

I must emphasize ...

At this point we must consider ...

To go back to my earlier point...

\section{WINDING UP}

Before closing I would like to summarize the main points again.

That's all I have to say for the moment . . .

Now if there are any questions I'll be happy to answer them.

\section{REFERENCES}

Cotton, D. (1988). Keys to management. Edinburgh, UK: Addison Wesley Longman.

De Rycker, T. (2001). Analyzing tables, graphs, and charts: A four-step approach. Business Communication Quarterly, 64(4), 72-82.

Morton, G. W. (2000). Combining a case study and original research in an extended writing assignment. Business Communication Quarterly, 63(2), 83-91.

Oakes, L. (2001, April). Perfect pitch. People Performance Magazine, pp. 11-12.

Address correspondence to Elizabeth Saatci, School of Applied Languages, Banking and

Finance, Bilkent University, 06533 Bilkent Ankara, Turkey; e-mail: saatci@bilkent.edu.tr. 
Copyright of Business Communication Quarterly is the property of Association for Business Communication and its content may not be copied or emailed to multiple sites or posted to a listserv without the copyright holder's express written permission. However, users may print, download, or email articles for individual use. 
Copyright of Business Communication Quarterly is the property of Association for Business Communication and its content may not be copied or emailed to multiple sites or posted to a listserv without the copyright holder's express written permission. However, users may print, download, or email articles for individual use. 